\title{
High thermoelectric performance of bornite through control of the Cu(II) content and vacancy concentration
}

Article

Accepted Version

Long, S. O. J., Powell, A. V., Vaqueiro, P. and Hull, S. (2018) High thermoelectric performance of bornite through control of the $\mathrm{Cu}(\mathrm{II})$ content and vacancy concentration. Chemistry of Materials, 30 (2). pp. 456-464. ISSN 1520-5002 doi: https://doi.org/10.1021/acs.chemmater.7b04436 Available at https://centaur.reading.ac.uk/74428/

It is advisable to refer to the publisher's version if you intend to cite from the work. See Guidance on citing.

To link to this article DOI: http://dx.doi.org/10.1021/acs.chemmater.7b04436

Publisher: American Chemical Society

All outputs in CentAUR are protected by Intellectual Property Rights law, including copyright law. Copyright and IPR is retained by the creators or other copyright holders. Terms and conditions for use of this material are defined in the End User Agreement.

www.reading.ac.uk/centaur 
Central Archive at the University of Reading

Reading's research outputs online 
Subscriber access provided by READING UNIV

\title{
Article
}

\section{High thermoelectric performance of bornite through control of the $\mathrm{Cu}$ (II) content and vacancy concentration}

\author{
Sebastian O. J. Long, Anthony V. Powell, Paz Vaqueiro, and Stephen Hull
}

Chem. Mater., Just Accepted Manuscript • DOI: 10.1021/acs.chemmater.7b04436 • Publication Date (Web): 13 Dec 2017

Downloaded from http://pubs.acs.org on December 15, 2017

\section{Just Accepted}

"Just Accepted" manuscripts have been peer-reviewed and accepted for publication. They are posted online prior to technical editing, formatting for publication and author proofing. The American Chemical Society provides "Just Accepted" as a free service to the research community to expedite the dissemination of scientific material as soon as possible after acceptance. "Just Accepted" manuscripts appear in full in PDF format accompanied by an HTML abstract. "Just Accepted" manuscripts have been fully peer reviewed, but should not be considered the official version of record. They are accessible to all readers and citable by the Digital Object Identifier (DOI®). "Just Accepted" is an optional service offered to authors. Therefore, the "Just Accepted" Web site may not include all articles that will be published in the journal. After a manuscript is technically edited and formatted, it will be removed from the "Just Accepted" Web site and published as an ASAP article. Note that technical editing may introduce minor changes to the manuscript text and/or graphics which could affect content, and all legal disclaimers and ethical guidelines that apply to the journal pertain. ACS cannot be held responsible for errors or consequences arising from the use of information contained in these "Just Accepted" manuscripts. 


\title{
High thermoelectric performance of bornite through control of the $\mathrm{Cu}(\mathrm{II})$ content and vacancy concentration
}

\author{
Sebastian O. J. Long, ${ }^{\mathrm{a}}$ Anthony V. Powell ${ }^{*},{ }^{\mathrm{a}}$ Paz Vaqueiro, ${ }^{\mathrm{a}}$ Stephen Hull ${ }^{\mathrm{b}}$ \\ a. Department of Chemistry, University of Reading, Whiteknights, Reading, RG6 6AD, UK. \\ b. ISIS Facility, Rutherford Appleton Laboratory, Harwell, Oxford, Didcot, OXı oOX, UK
}

\begin{abstract}
The thermoelectric performance of the p-type semiconductor bornite, $\mathrm{Cu}_{5} \mathrm{FeS}_{4}$, is greatly enhanced through chemical substitution. Non-stoichiometric materials in which the $\mathrm{Cu}$ :Fe ratio and overall cation-vacancy content were adjusted are reported and a figure of merit, $\mathrm{ZT}=0.79$, is achieved at temperatures as low as $550 \mathrm{~K}$ in $\mathrm{Cu}_{4.972} \mathrm{Fe}_{0.968} \mathrm{~S}_{4}$. All materials were synthesised mechanochemically and characterised by powder X-ray diffraction, DSC and thermal and electrical transport property measurements. Single-phase behaviour is retained in copper deficient phases, $\mathrm{Cu}_{5-\mathrm{x}} \mathrm{FeS}_{4}$, for vacancy levels up to $\mathrm{x}=0.1$, while in materials $\mathrm{Cu}_{5+\mathrm{y}} \mathrm{Fe}_{1-\mathrm{y}} \mathrm{S}_{4}$, in which the $\mathrm{Cu}$ :Fe ratio is varied whilst maintaining full occupancy of cation sites, single-phase behaviour persists for $\mathrm{y} \leq \mathbf{0 . 0 8}$. Adjusting the $\mathrm{Cu}: \mathrm{Fe}$ ratio at a constant cation-vacancy level of 0.06 in $\mathrm{Cu}_{4 \cdot 94+\mathrm{z}} \mathrm{Fe}_{1-\mathrm{z}} \mathrm{S}_{4}$, leads to singlephases for $\mathrm{z} \leq \mathbf{0 . 0 4}$. DSC measurements indicate the temperature of the intermediate- (2a) to high-temperature (a) phase transition shows a more marked dependence on the Cu:Fe ratio than the lower temperature 4 a to $2 a$ transition. The thermoelectric power factor increases almost linearly with increasing $\mathrm{Cu}$ (II) content. The maximum figures of merit are obtained for materials with $\mathrm{Cu}(\mathrm{II})$ contents in the range 0.10 to 0.15 (corresponding to $2.0-2.8 \% \mathrm{Cu}(\mathrm{II}))$ which simultaneously contain ca. $1 \%$ of cation vacancies.
\end{abstract}

\section{Introduction}

Thermoelectric (TE) materials have the potential to generate electrical energy from otherwise waste heat. ${ }^{1}$ This offers opportunities to achieve more efficient use of precious fossil fuel resources ${ }^{2}$ and also to enhance the energy recovery from renewable sources such as photovoltaic devices. ${ }^{3,4}$ Of the range of sources of waste heat available, that produced in industrial processes offers particularly attractive prospects for large-scale implementation of TE technology. Over $80 \%$ of the waste heat generated in industrial processes is at temperatures in the range $373 \leq \mathrm{T} / \mathrm{K} \leq 575,{ }^{5,6}$ suggesting considerable opportunities exist for the development of efficient TE materials that operate in this region.

Current commercial thermoelectric devices are based on bismuth telluride., ${ }^{7,8}$ The combination of the low abundance of tellurium coupled with comparatively low TE efficiencies has restricted wide-scale adoption of TE technology. This has led to a major world-wide research effort to develop new materials for thermoelectric energy conversion. Whilst significant advances have been achieved in the figure of merit $\left(\mathrm{ZT}=\mathrm{S}^{2} \sigma \mathrm{T} / \kappa\right)$ at high temperatures, there remains a dearth of materials suitable for energy recovery from waste heat in the low to mid-range of temperatures appropriate to industrial processes.
Much of the recent research effort has focused on chalcogenides and there has been a growing realisation that mineral-type phases offer considerable potential as earthabundant thermoelectrics. ${ }^{9-15}$ For example, tetrahedrites have been shown to be promising p-type materials, reaching maximum figures of merit, ZT $>1$, at elevated temperatures. ${ }^{16,17}$ Similarly, work by Snyder et. al. ${ }^{18}$ has shown that a non-stoichiometric cuprous sulphide, $\mathrm{Cu}_{2-\mathrm{x}} \mathrm{S}$, exhibits an exceptionally low thermal conductivity, which results in a figure-of-merit, ZT $=1.7$ at $1000 \mathrm{~K}$. It has been suggested that this remarkably low value for a crystalline phase arises from the copper sub-lattice entering a liquidlike state on heating, due to the high-mobility of the copper cations. ${ }^{19}$ The combination of a liquid-like thermal conductivity with electrical transport properties determined by the crystalline sulphide sub-lattice has led this class of material to be termed Phonon-Liquid ElectronCrystals (PLECs). ${ }^{19,20}$ However, despite the high performance, the copper-ion mobility in $\mathrm{Cu}_{2-\mathrm{x}} \mathrm{S}$ leads to degradation of the material through ion migration under constant current. ${ }^{21,22}$ Therefore there is growing interest in discovering alternative materials with PLEC characteristics, in which ion migration can be suppressed.

Bornite, $\mathrm{Cu}_{5} \mathrm{FeS}_{4}$, is an abundant copper-iron sulphide mineral which at high temperatures adopts a cationdeficient anti-fluorite structure similar to that of $\mathrm{Cu}_{2-\mathrm{x}} \mathrm{S}$. Stoichiometric bornite possesses a similarly low thermal 
conductivity to $\mathrm{Cu}_{2-\mathrm{x}} \mathrm{S}$. However, the presence of iron on the cation sites helps suppress copper ion migration, with no significant degradation in electronic properties occurring when a test sample is maintained under constant current. ${ }^{23}$ Bornite-related phases are therefore promising candidates for TE applications, providing the low power factor $\left(S^{2} \sigma\right)$ of stoichiometric bornite can be improved.

Above $530 \mathrm{~K}$, bornite adopts an anti-fluorite type structure (Fig. 1) in which the cubic unit cell (space group: Fm $\overline{3} \mathrm{~m}$ ) contains two cation vacancies. ${ }^{24,25}$ These, together with the copper and iron cations, are distributed over the eight available cation sites in a statistical fashion. On cooling below $540 \mathrm{~K}$, ordering of vacancies results in a supercell with lattice parameters related to those of the cubic high-temperature phase $\left(a_{\mathrm{p}}\right)$ by $2 a_{\mathrm{p}} \times 2 a_{\mathrm{p}} \times 2 a_{\mathrm{p}}$ (Fig. $1 b)$, termed the 2a structure. Further cooling below $460 \mathrm{~K}$, leads to an orthorhombic (space group Pbca) ${ }^{26} 4 a_{\mathrm{p}} \times 2 a_{\mathrm{p}} \times$ $2 a_{\mathrm{p}}$ unit cell, denoted $4 \mathrm{a}$, in which zinc blende and antifluorite sub-cells alternate. Although the distribution of copper and iron cations in the $4 \mathrm{a}$ and $2 \mathrm{a}$ structures has not been established unambiguously, ordering schemes have been suggested by Ding et. al. ${ }^{27}$

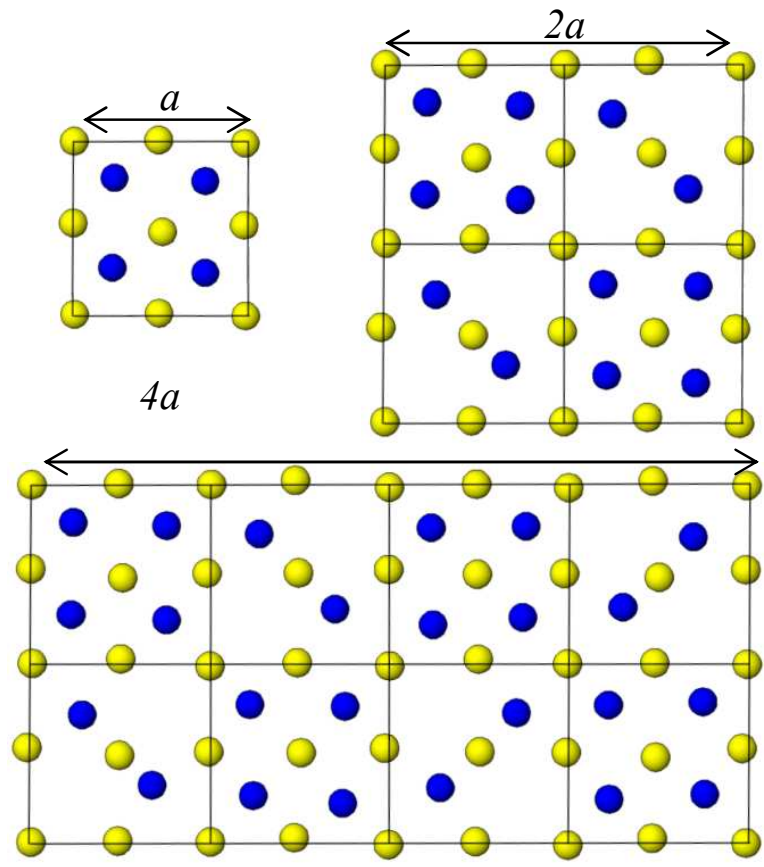

Figure 1. View of the vacancy ordering in the three phases of $\mathrm{Cu}_{5} \mathrm{FeS}_{4}$ : (a) high-temperature phase (2a) intermediatetemperature phase (4a) low-temperature phase. Key: $\mathrm{Cu} / \mathrm{Fe}$, blue circles; S, yellow circles. Zinc-blende and anti-fluorite unit cells are outlined.

Here, we describe how the electron-transport properties of bornite may be markedly improved through judicious control of composition and cation-vacancy levels. We demonstrate that significant enhancements in the power factor $\left(\mathrm{S}^{2} \sigma\right)$ may be achieved without impacting on the thermal conductivity $(\kappa)$. This leads to an increase of up to $88 \%$ in the figure of merit, with a maximum value of $\mathrm{ZT}=0.79$ being attained in $\mathrm{Cu}_{4.972} \mathrm{Fe}_{0.968} \mathrm{~S}_{4}$ at the remarka- bly low temperature of $550 \mathrm{~K}$ : a temperature directly relevant to low-grade waste heat.

\section{Experimental Procedure and Synthesis}

2.1 Starting material and synthesis. All samples were prepared from mixtures of copper, (99.5\%, Sigma Aldrich) iron (99.9+\%, Sigma Aldrich) and sulphur (flakes, 99.99\%, Sigma Aldrich) of the appropriate stoichiometry. After grinding mixtures of the powdered elements together in an agate mortar, the mixture was placed in a 25 $\mathrm{mL}$ stainless-steel jar under an argon atmosphere and $6 \mathrm{~mm}$ stainless-steel balls added (2:5 mass ratio of powder to balls). Two successive millings, each of $20 \mathrm{~h}$, were carried out using a Retsch PMioo Planetary Ball Mill operating at $500 \mathrm{rpm}$ with a change of rotational direction every 5 mins, The resulting powder was loaded into a tungsten carbide mould, sandwiched between graphite foils and tungsten carbide plungers. The mould was heated to 823 $\mathrm{K}$, under a nitrogen atmosphere, and a pressure of 90 MPa applied for 30 minutes in order to consolidate the powder.

Three series of materials were prepared: $\mathrm{Cu}_{5-x} \mathrm{FeS}_{4}$ ($0.08 \leq \mathrm{x} \leq 0.16)$ allowed exploration of the impact of varying copper content at a fixed iron content, whilst $\mathrm{Cu}_{5+y} \mathrm{Fe}_{1-}$ ${ }_{\mathrm{y}} \mathrm{S}_{4}(0.02 \leq \mathrm{y} 0.10)$ and $\mathrm{Cu}_{4.94+\mathrm{z}} \mathrm{Fe}_{1-\mathrm{z}} \mathrm{S}_{4}(0.02 \leq \mathrm{z} \leq 0.10)$ enabled investigation of the effect of the substitution of copper for iron at a constant overall cation content, corresponding to a fully occupied or cation-deficient cation sub-lattice respectively.

2.3 Sample Characterization. Consolidated samples were polished by hand, producing cylindrical pellets with a diameter ca. $12.66 \mathrm{~mm}( \pm 0.03 \mathrm{~mm})$ and thickness between 1-2mm $( \pm 0.03 \mathrm{~mm})$. Densities were measured on an Archimedes ADAM PW184 balance. Sample densities were close (> 98\%) to the crystallographic density of stoichiometric bornite. Powder X-Ray diffraction data were collected using a Bruker D8 Advance $\left(\mathrm{Cu}-\mathrm{K}_{\alpha 1}: \lambda=1.5405 \AA\right)$ diffractometer fitted with a LynxEye linear detector and a Ge monochromator. All Le Bail refinements using powder X-ray diffraction data were carried out using the GSAS software package. ${ }^{28}$

Elemental compositions were determined using EDX on a FEI Quanta FEG 6oo Environmental Scanning Electron Microscope (ESEM) under a high-vacuum, using a maximum voltage of $20 \mathrm{kV}$ on pelletized samples. An Oxford Instruments EDX spectrometer was used, calibrated using a standard block supplied by Micro-Analysis Consultants Ltd. DSC measurements were carried out on a TA DSC20oo instrument on powdered samples loaded into aluminium pans. Data were collected on both heating and cooling with heating and cooling rates of $10 \mathrm{~K} \mathrm{~min}^{-1}$ and $20 \mathrm{~K} \mathrm{~min}^{-1}$ respectively. The $4 \mathrm{a} \rightarrow 2 \mathrm{a}(\mathrm{T} 1)$ transition temperature was determined from the peak maximum whilst the $2 a \rightarrow a\left(T_{2}\right)$ transition temperature was determined from the change in gradient, owing to the glass-like nature of the DSC transition.

2.4 Transport Properties. Thermoelectric property data were collected over the temperature range $300 \leq \mathrm{T} / \mathrm{K}$ 
$\leq 580$. The upper limit for the collection of physical property data was selected following the observation by Guelou et al. that stoichiometric bornite $\left(\mathrm{Cu}_{5} \mathrm{FeS}_{4}\right)$ begins to lose sulphur above $600 \mathrm{~K}$ under a flowing nitrogen atmosphere. $^{29}$ The electrical resistivity, ( $\left.\rho\right)$, and Seebeck coefficient, (S), were measured simultaneously under a slight over pressure of He using a Linseis LSR-3 instrument. A gradient of $50 \mathrm{~K}$ was maintained across the sample for the measurement of the Seebeck coefficient. The resistivity was measured using a 4-probe DC method, with the two central thermocouple probes ( $8 \mathrm{~mm}$ separation) aligned perpendicular to the terminal Pt electrodes.

The thermal diffusivity of graphite coated pellets was measured using a Netzsch LFA 447 NanoFlash system over the temperature range $300 \leq \mathrm{T} / \mathrm{K} \leq 580$. Higher temperature measurements $(573 \leq \mathrm{T} / \mathrm{K} \leq 700 \mathrm{~K})$ were performed using an Anter Flashline 3000 instrument. Data were analysed using Cowan's model with a pulse correction applied..$^{30}$ The thermal conductivity was determined using the calculated Dulong-Petit heat capacity for $\mathrm{Cu}_{5} \mathrm{FeS}_{4}\left(\mathrm{C} \mathrm{p}=0.497 \mathrm{~J} \mathrm{~K}^{-1} \mathrm{~g}^{-1}\right)$.

\section{Results and Discussion}

3.1 Structural Characterisation and Phase Behaviour. Powder X-Ray diffraction data for the product of hot pressing a ball-milled mixture of composition $\mathrm{Cu}_{5} \mathrm{FeS}_{4}$ are indexable on the basis of an orthorhombic unit cell, $\mathrm{a}=10.953(1) \AA, \mathrm{b}=21.8694(16) \AA, c=10.9464$ (10) $\AA$, consistent with the formation of a single phase of the lowtemperature (4a) phase of stoichiometric bornite. Whilst HRTEM studies by Ding et. al. suggest that domains of 1a, 2a, $4 \mathrm{a}$ and $6 \mathrm{a}$ may exist at room temperature, ${ }^{31}$ analysis of the powder X-ray diffraction data presented here (Fig. 2) provide no evidence for the presence of domains of this type.

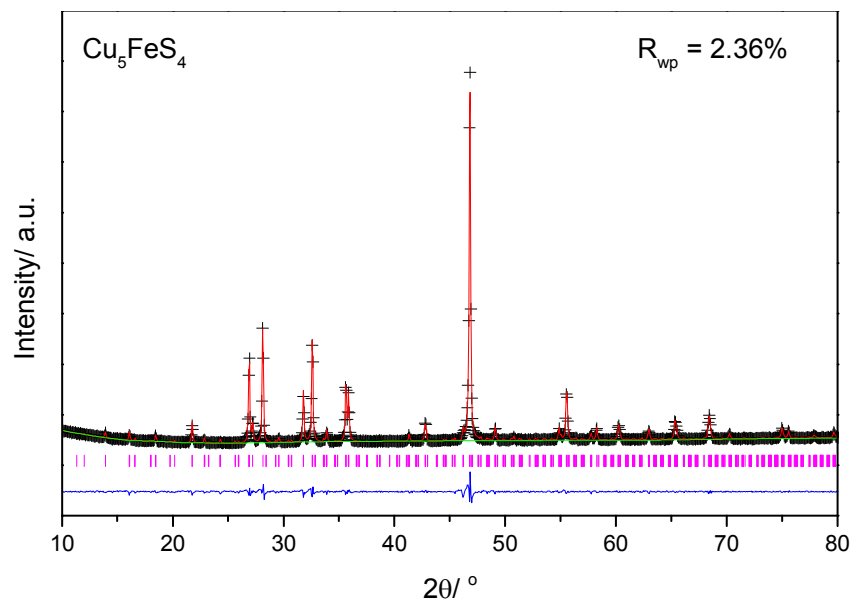

Figure 2. Powder X-ray diffraction data for $\mathrm{Cu}_{5} \mathrm{FeS}_{4}$, together with analysis by the structure-independent Le Bail method, where the observed, calculated and difference profiles are denoted by crosses, the red solid line and the lower full line respectively. Markers represent the reflection positions for the low-temperature phase of $\mathrm{Cu}_{5} \mathrm{FeS}_{4}$ (space group Pbca).

Powder X-ray diffraction data for materials in the series $\mathrm{Cu}_{5-\mathrm{x}} \mathrm{FeS}_{4}(-0.08 \leq \mathrm{x} \leq 0.16)$ show the presence of a bornite- related phase, indexable on an analogous unit cell to that for the stoichiometric phase, at all compositions. Reflections arising from a chalcopyrite $\left(\mathrm{CuFeS}_{2}\right)$ impurity are evident at $x \geq 0.10$ (Fig. 3a). Within the detection limits of powder $\mathrm{X}$-ray diffraction, samples with $\mathrm{x}<0.10$ are single phase. The lattice parameters of the bornite-type phase (Supplementary Information) are relatively insensitive to the total copper content; variations of $<1 \%$ being observed in the orthorhombic lattice parameters across the entire range of compositions investigated.

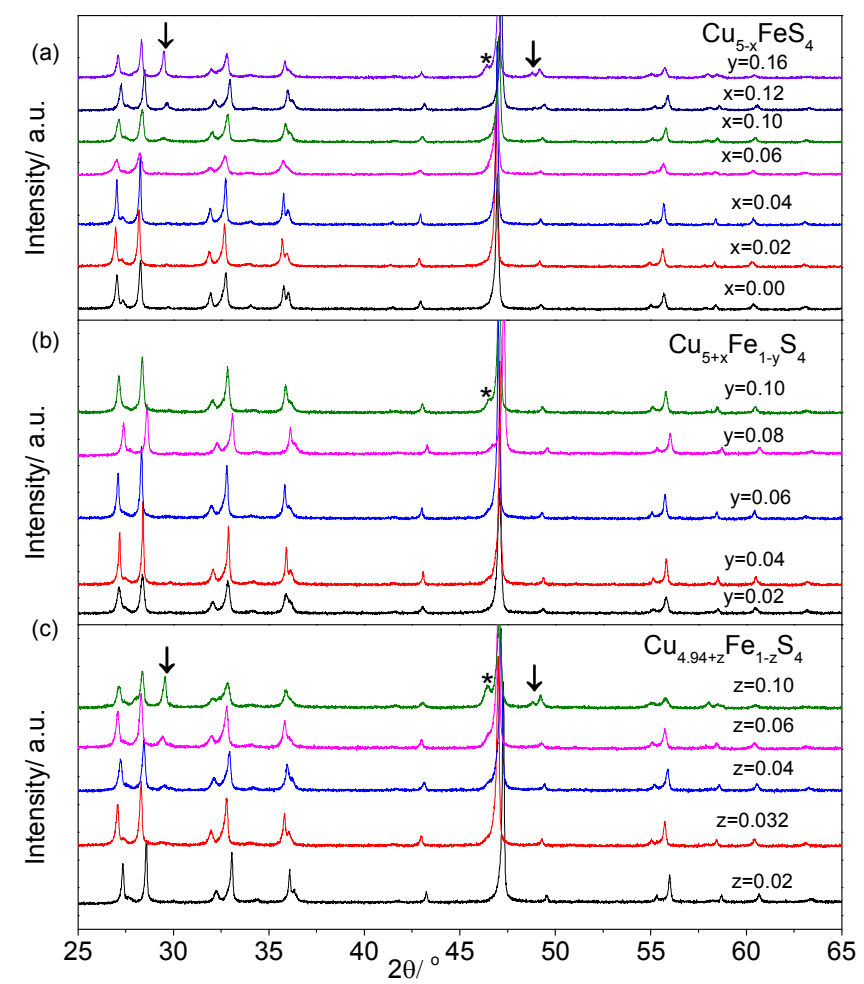

Figure 3. Powder X-Ray Diffraction patterns for selected bornite samples in the series (a) $\mathrm{Cu}_{5-\mathrm{x}} \mathrm{FeS}_{4}$, (b) $\mathrm{Cu}_{5+y} \mathrm{Fe}_{1-y} \mathrm{~S}_{4}$ and (c) $\mathrm{Cu}_{4 \cdot 94+z} \mathrm{Fe}_{1-\mathrm{z}} \mathrm{S}_{4}$, over the angular range $25 \leq \theta /{ }^{\circ} \leq 65$. Peaks corresponding to a $\mathrm{CuFeS}_{2}$ impurity have been marked with an arrow, and those corresponding to $\mathrm{Cu}_{1.8} \mathrm{~S}$ with an asterix.

Powder X-ray diffraction data (Fig. 3b) for materials in the series $\mathrm{Cu}_{5+\mathrm{y}} \mathrm{Fe}_{1-\mathrm{y}} \mathrm{S}_{4}$ reveal single phase behaviour up to $y=0.08$. At higher values of $y$, there is evidence for the formation of trace amounts of a digenite $\left(\mathrm{Cu}_{1.8} \mathrm{~S}\right)$ impurity. Lattice parameters (Supplementary Information) show a similarly low sensitivity to composition as the copper deficient phases described above, with $<1 \%$ variation being observed in each of the orthorhombic unit-cell parameters across the series.

The investigation of the impact of the substitution of copper for iron in cation-deficient phases $\left(\mathrm{Cu}_{4 \cdot 94+\mathrm{Z}} \mathrm{Fe}_{1-\mathrm{z}} \mathrm{S}_{4}\right)$ establishes an upper limit of $\mathrm{z} \leq 0.04$ for single-phase behaviour. Powder X-ray diffraction data (Fig. 3c) reveal that at increasing levels of copper substitution, a chalcopyrite impurity is formed, with digenite appearing at the highest level of non-stoichiometry $(\mathrm{z}=0.1)$. The orthorhombic lattice parameters of the bornite-type phase (Supplementary Information) again show $<1 \%$ variation 
across the range of composition. Contrary to the behaviour of fully-stoichiometric bornite-type phases $\left(\mathrm{Cu}_{5+y} \mathrm{Fe}_{1-}\right.$ ${ }_{\mathrm{y}} \mathrm{S}_{4}$ ), where impurities appear at $\mathrm{Cu}$ :Fe ratios above ${ }_{5.52}$, in cation-deficient phases chalcopyrite formation occurs above a lower $\mathrm{Cu}: \mathrm{Fe}$ threshold of 5.19:1. This suggests there is a complex dependence of the phase behaviour on the composition and defect concentration in this region of the copper-iron-sulphur phase diagram.

Table 1. Elemental compositions for selected samples determined by EDX analysis.

\begin{tabular}{l|l} 
Nominal & Experimental \\
\hline $\mathrm{Cu}_{5} \mathrm{FeS}_{4}$ & $\mathrm{Cu}_{5.00(2)} \mathrm{Fe}_{\text {o.99(1) }} \mathrm{S}_{4}$ \\
$\mathrm{Cu}_{4.94} \mathrm{FeS}_{4}$ & $\mathrm{Cu}_{4 \cdot 91(2)} \mathrm{Fe}_{1.00(1)} \mathrm{S}_{4}$ \\
$\mathrm{Cu}_{4 \cdot 9} \mathrm{FeS}_{4}$ & $\mathrm{Cu}_{4.85(2)} \mathrm{Fe}_{1.05(1)} \mathrm{S}_{4}$ \\
$\mathrm{Cu}_{5.06} \mathrm{FeS}_{4}$ & $\mathrm{Cu}_{5 \cdot 14(1)} \mathrm{Fe}_{\text {o.91(1) }} \mathrm{S}_{4}$ \\
$\mathrm{Cu}_{5.08} \mathrm{Fe}_{0.92} \mathrm{~S}_{4}$ & $\mathrm{Cu}_{5.06(2)} \mathrm{Fe}_{\text {o.94(1) }} \mathrm{S}_{4}$ \\
$\mathrm{Cu}_{4.972} \mathrm{Fe}_{0.968} \mathrm{~S}_{4}$ & $\mathrm{Cu}_{4.89(2)} \mathrm{Fe}_{1.02(1)} \mathrm{S}_{4}$
\end{tabular}

The iron and copper contents of selected pelletized samples, determined experimentally by Analytical Electron Microscopy (EDX), are in reasonable agreement with the nominal compositions (Table 1).

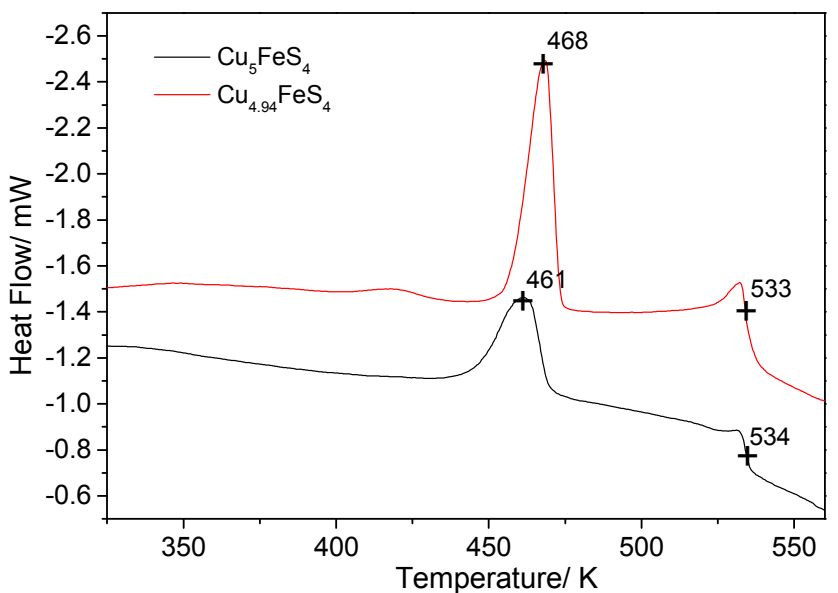

Figure 4. DSC data collected on heating for two bornite samples. Transition temperatures are shown.

DSC data collected on $\mathrm{Cu}_{5} \mathrm{FeS}_{4}$ on heating (Fig. 4) show two transitions at ca. 470 and $530 \mathrm{~K}$, with a degree of hysteresis. These features can be assigned to the $\mathrm{T}_{1}(4 \mathrm{a} \rightarrow 2 \mathrm{a})$ and $\mathrm{T}_{2}$ ( $2 \mathrm{a}$ $\rightarrow$ a) phase transitions respectively. DSC data (Supplementary information) for materials of general formula $\mathrm{Cu}_{5-\mathrm{x}} \mathrm{FeS}_{4}$ reveal that the introduction of cation vacancies has little effect on the $\mathrm{T} 2$ transition for compositions in the range $-0.08 \leq \mathrm{x} \leq 0.1$, whilst the temperature of the lower temperature $\mathrm{T} 1$ transition decreases slightly with increasing $\mathrm{x}$ for $\mathrm{x} \geq$ o.02. In the $\mathrm{Cu}_{5+y} \mathrm{Fe}_{1-y} \mathrm{~S}_{4}$ series, DSC data (Supplementary Information) show that the $\mathrm{T} 2$ transition temperature decreases from $534 \mathrm{~K}$ when $\mathrm{y}=\mathrm{o}$ to $515 \mathrm{~K}$ when $\mathrm{y}=0.1$, indicating that, at a constant vacancy concentration, the $\mathrm{T}_{2}$ phase transition is sensitive to the $\mathrm{Cu}: \mathrm{Fe}$ ratio. The $\mathrm{T} 1$ transition temperature shows a markedly weaker dependence on the $\mathrm{Cu}$ :Fe ratio. The behaviour of the $\mathrm{Cu}_{4 \cdot 94+\mathrm{z}} \mathrm{Fe}_{1-\mathrm{z}} \mathrm{S}_{4}$ series (Supplementary Information) is similar to that of $\mathrm{Cu}_{5+\mathrm{y}} \mathrm{Fe}_{1-\mathrm{y}} \mathrm{S}_{4}$, with the $\mathrm{T}_{2}$ phase transition temperature showing a marked dependence on the $\mathrm{Cu}: \mathrm{Fe}$ ratio. The presence of impurities of $\mathrm{Cu}_{1.8} \mathrm{~S}$ in the more highly-substituted copper-iron sulphides, results in an additional transition at ca. $370 \mathrm{~K}$ (Supplementary Information) corresponding to the low-to-high temperature phase transition of digenite. ${ }^{32,33}$ These results are broadly consistent with a previous DSC study on a range of natural and synthetic samples of bornite, which concluded that the temperature of the $\mathrm{T} 2$ phase transition is linearly dependent on the $\mathrm{Cu}: \mathrm{Fe}$ ratio and the $\mathrm{Fe}$ content, whilst no correlation is observed between the $\mathrm{T}_{1}$ phase transition temperature and the composition. ${ }^{33}$

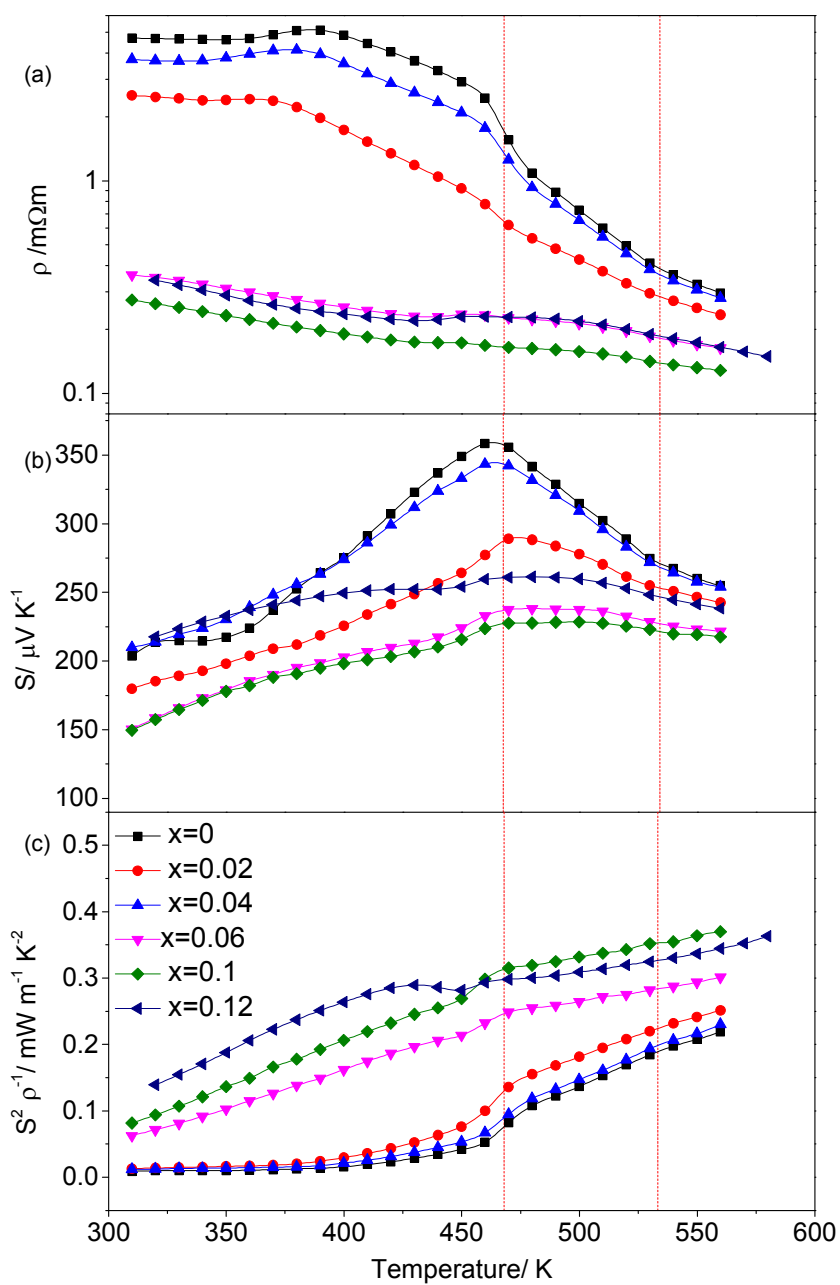

Figure 5. Temperature dependence of the electrical transport properties of $\mathrm{Cu}_{5-\mathrm{x}} \mathrm{FeS}_{4}(\mathrm{o} \leq \mathrm{x} \leq 0.12)$ : (a) electrical resistivity; (b) Seebeck coefficient; (c) power factor. Red vertical lines indicate the temperatures of the $\mathrm{T}_{1}$ and $\mathrm{T}_{2}$ structural phase transitions in $\mathrm{Cu}_{5} \mathrm{FeS}_{4}$.

3.2 Thermoelectric Properties. The physical properties of the stoichiometric parent compound, $\mathrm{Cu}_{5} \mathrm{FeS}_{4}$, are in excellent agreement with those from previous work on the TE properties of bornite ${ }^{23,29,34,35}$ and provide a benchmark for the investigation of the non-stoichiometric materials. The Seebeck coefficient of $\mathrm{Cu}_{5} \mathrm{FeS}_{4}$ exhibits a maximum of ca. $350 \mu \mathrm{V} \mathrm{K}^{-1}$ at $46 \mathrm{o} \mathrm{K}$ (Fig. 5), and remains positive over the entire temperature range investigated, indicating that holes are the dominant charge carriers throughout. The temperature dependence of the electrical 
resistivity is consistent with semiconducting behaviour and shows an anomaly at the temperature of the $\mathrm{T} 1$ phase transition, coinciding with the maximum in the Seebeck coefficient. By contrast, there is little signature of the higher temperature $\mathrm{T}_{2}$ phase transition in the electrical property data. However, the T2 phase transition is reflected in the minimum in the thermal conductivity (ca. o.3 W $\mathrm{m}^{-1} \mathrm{~K}^{-1}$ ) of $\mathrm{Cu}_{5} \mathrm{FeS}_{4}$ (Fig. 6) at $550 \mathrm{~K}$. The maximum value of the figure of merit for stoichiometric bornite, $\mathrm{ZT}=0.44$ at $550 \mathrm{~K}$, is in good agreement with previous reports of the figure of merit at $550 \mathrm{~K}$, which indicate values in the range $0.3 \leq \mathrm{ZT} \leq 0.55^{23,29,34,35}$

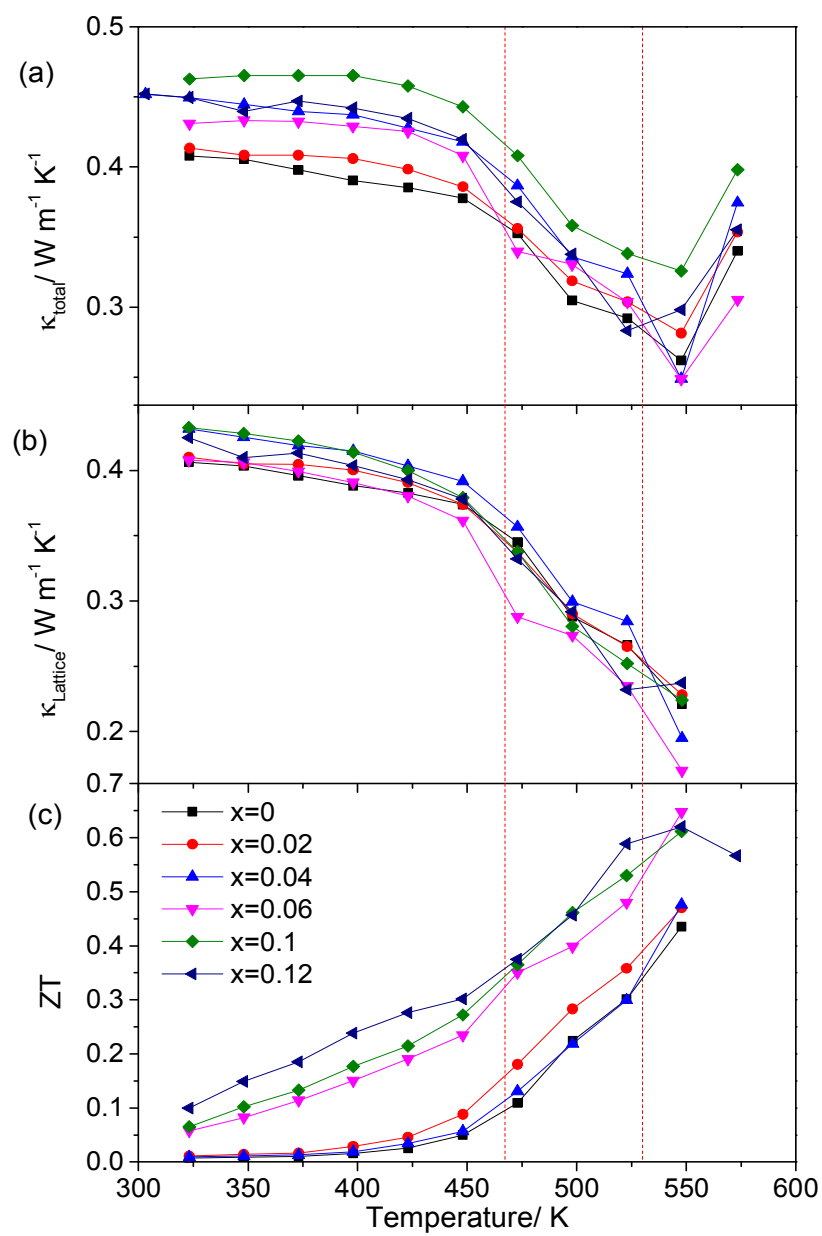

Figure 6. Temperature dependence of: (a) thermal conductivity; (b) lattice thermal conductivity; (c) thermoelectric figure of merit for $\mathrm{Cu}_{5-\mathrm{x}} \mathrm{FeS}_{4}(\mathrm{o} \leq \mathrm{x} \leq 0.12)$. Red vertical lines indicate the temperatures of the $\mathrm{T}_{1}$ and $\mathrm{T}_{2}$ structural phase transitions in $\mathrm{Cu}_{5} \mathrm{FeS}_{4}$.

Electrical measurements for $\mathrm{Cu}_{5-x} \mathrm{FeS}_{4}$ materials with both increased $(\mathrm{x}<0)$ and decreased $(\mathrm{x}>0)$ copper contents were attempted. However, materials in the former category exhibit relatively high electrical resistivities (e.g. $\rho=86 \mathrm{~m} \Omega \mathrm{m}$ at $300 \mathrm{~K}$ for $\mathrm{x}=-0.06$ ), preventing full thermoelectric characterisation. Therefore compositions in the range $-0.8<\mathrm{x}<0.0$ will not be discussed further. For copper deficient materials, $\mathrm{Cu}_{5-\mathrm{x}} \mathrm{FeS}_{4},(0.0<\mathrm{x} \leq 0.12)$ (Fig. 5), $\rho(\mathrm{T})$ is consistent with semiconducting behaviour throughout the compositional range. With increasing levels of copper deficiency the resistivity and the Seebeck coefficient decrease. Given the formulation $\mathrm{Cu}_{5}{ }_{5} \mathrm{Fe}^{\mathrm{III}} \mathrm{S}_{4}$ of the end-member phase proposed by Townsend et. al., ${ }^{36}$ on the basis of Mössbauer spectroscopic and magnetic data, reducing the copper content would be expected to result in an increase in the concentration of holes, which would account for the observed reduction in electrical resistivity. The anomaly in both $\rho(\mathrm{T})$ and $\mathrm{S}(\mathrm{T})$ in the region of the $\mathrm{T} 2$ transition is less marked for compositions in the middle of the range investigated.

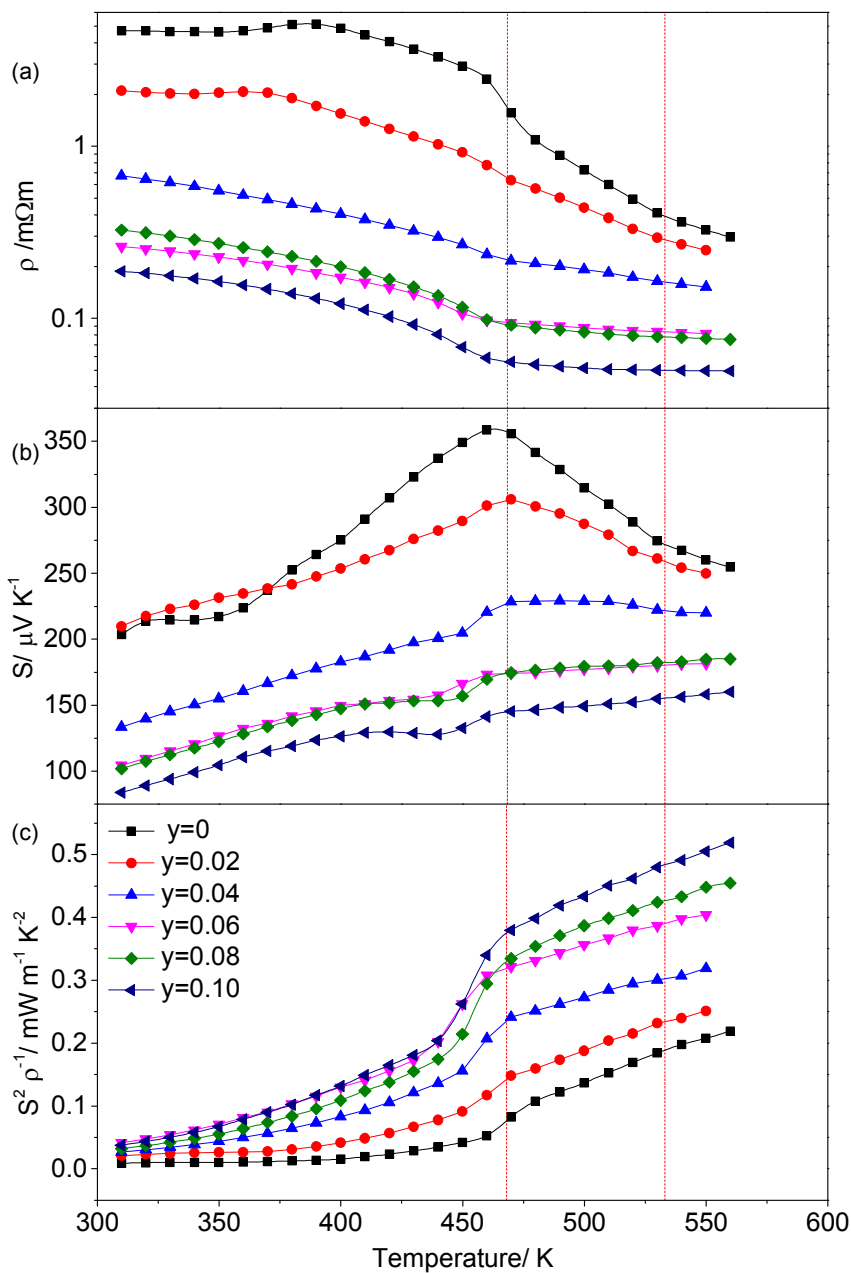

Figure 7. Temperature dependence of the electrical transport properties of $\mathrm{Cu}_{5+y} \mathrm{Fe}_{1-y} \mathrm{~S}_{4}(\mathrm{o} \leq \mathrm{y} \leq \mathrm{o.1})$ : (a) electrical resistivity; (b) Seebeck coefficient; (c) power factor. Red vertical lines indicate the temperatures of the $\mathrm{T}_{1}$ and $\mathrm{T}_{2}$ structural phase transitions in $\mathrm{Cu}_{5} \mathrm{FeS}_{4}$.

All materials of general formula, $\mathrm{Cu}_{5-\mathrm{x}} \mathrm{FeS}_{4}$, exhibit a low thermal conductivity for compositions with $\mathrm{x} \leq 0.12$ : values at room temperature lying the in the range $0.4-0.5$ $\mathrm{W} \mathrm{m} \mathrm{m}^{-1} \mathrm{~K}^{-1}$ (Fig. 6). Materials with $\mathrm{x}<0.12$ exhibit a minimum in $\kappa(\mathrm{T})$ at temperatures (ca. $55^{\circ} \mathrm{K}$ ) in the region of the $\mathrm{T}_{2}$ phase transition. Whilst the thermal conductivity for materials in this compositional range shows little dependence on copper content, the lattice contribution to the thermal conductivity $\left(\kappa_{\mathrm{L}}\right)$, determined by subtraction of the electronic component calculated using the 
Wiedemann-Franz law $\left(\mathrm{L}=2.44 \times 10^{-8} \mathrm{~W} \Omega \mathrm{K}^{-2}\right)$, suggests that copper deficiency increases $\kappa_{\mathrm{L}}$ slightly from that of the stoichiometric parent compound (Fig. 6). All samples in this series exhibit an increase in thermoelectric performance when compared to the parent bornite phase, ${ }^{23,29}$ with considerable enhancements in the figure of merit: $0.61<(\mathrm{ZT})_{\max }<0.65$ (Fig. 6), being achieved for compositions with $0.06 \leq \mathrm{x} \leq 0.12$.

Resistivity data for materials of general formula $\mathrm{Cu}_{5+\mathrm{y}} \mathrm{Fe}_{1-\mathrm{y}} \mathrm{S}_{4}$ are consistent with semiconducting behaviour (Fig. 7). The resistivity shows substantial reductions with increasing copper content, as the hole concentration increases. There is a concomitant reduction in Seebeck coefficient, which remains positive at all compositions and temperatures. The decrease in resistivity outweighs the reduction in Seebeck coefficient and as result the TE power factor increases with increasing copper content, exceeding $0.4 \mathrm{~mW} \mathrm{~m}^{-1} \mathrm{~K}^{-2}$ at $\mathrm{x}>0.04$ (Fig. 7).

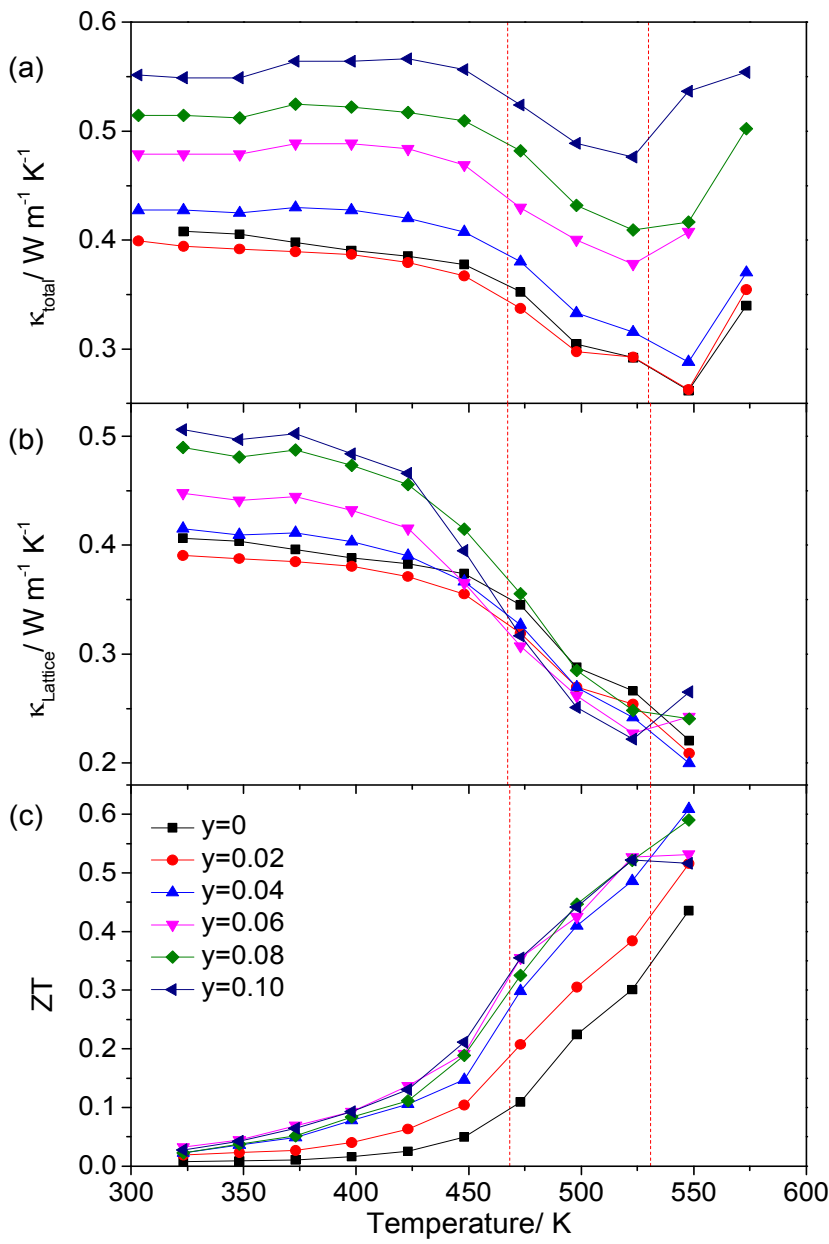

Figure 8. Temperature dependence of: (a) thermal conductivity; (b) lattice thermal conductivity; (c) thermoelectric figure of merit for $\mathrm{Cu}_{5+y} \mathrm{Fe}_{1-\mathrm{y}} \mathrm{S}_{4}(\mathrm{o} \leq \mathrm{y} \leq \mathrm{o.1})$. Red vertical lines indicate the temperatures of the $\mathrm{T}_{1}$ and $\mathrm{T}_{2}$ structural phase transitions in $\mathrm{Cu}_{5} \mathrm{FeS}_{4}$.

All materials in the $\mathrm{Cu}_{5+\mathrm{y}} \mathrm{Fe}_{1-\mathrm{y}} \mathrm{S}_{4}$ series exhibit a thermal conductivity below $0.6 \mathrm{~W} \mathrm{~m}^{-1} \mathrm{~K}^{-1}$ (Fig. 8): the value increasing with increasing copper content. This is due to the increased charge-carrier contribution, $\kappa_{\mathrm{e}}$, evidenced by the reduction in electrical resistivity. There is a minimum in $\kappa(T)$ in the region of the $\mathrm{T} 2$ phase transition. The reduction in the temperature at which this minimum occurs with increasing copper content, is consistent with the change in the temperature of the $\mathrm{T} 2$ transition determined using DSC. The decreasing thermal conductivity, as the $T_{2}$ phase transition is approached, coupled with the increase in power factor, results in a significant enhancement in the figure of merit for materials over the entire range of compositions studied and maximum values exceed $\mathrm{ZT}=0.59$ at compositions corresponding to $\mathrm{x}=0.04$ and 0.08 . This is consistent with the observations of Qiu et. al. ${ }^{23}$ who report that slight deviations from a 5:1 $\mathrm{Cu}$ :Fe ratio results in improvements in thermoelectric performance.

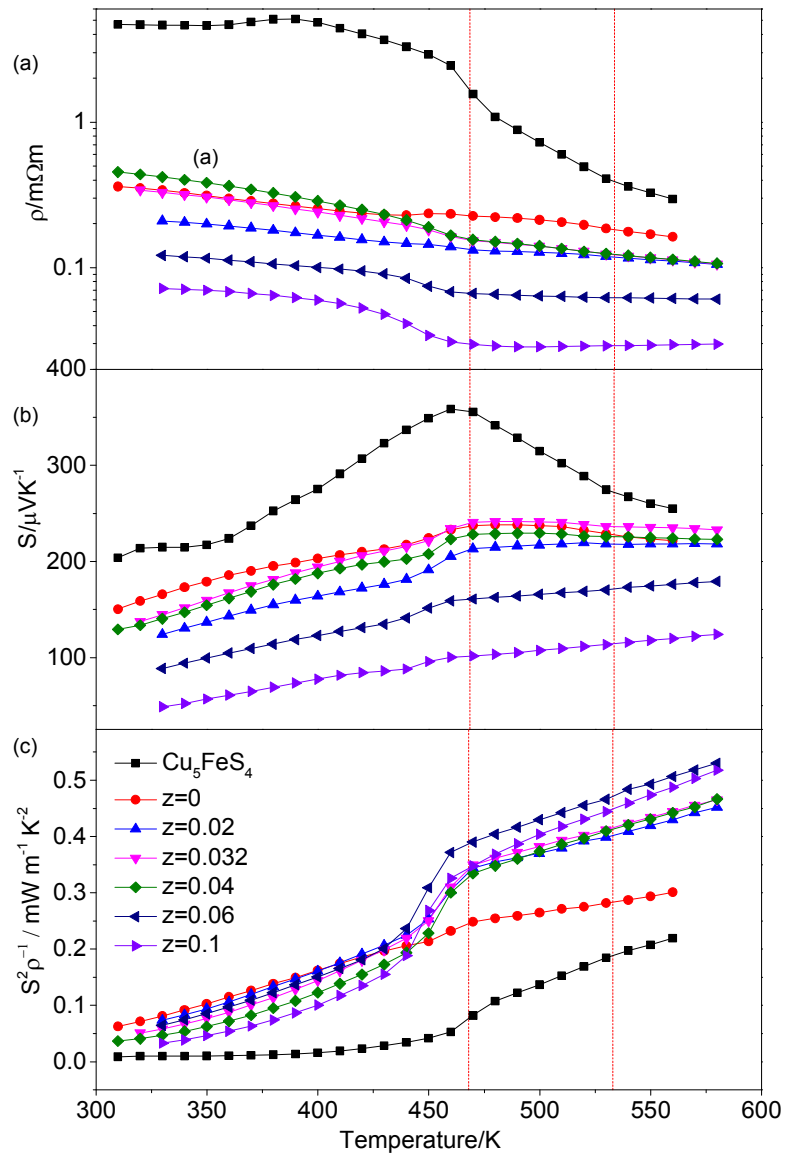

Figure 9. Temperature dependence of the electrical transport properties for $\mathrm{Cu}_{4.94+\mathrm{z}} \mathrm{Fe}_{1-\mathrm{z}} \mathrm{S}_{4}(\mathrm{o} \leq \mathrm{z} \leq \mathrm{0.1})$ : (a) electrical resistivity; (b) Seebeck coefficient; (c) power factor. Red vertical lines indicate the temperatures of the $\mathrm{T}_{1}$ and $\mathrm{T}_{2}$ structural phase transitions in $\mathrm{Cu}_{5} \mathrm{FeS}_{4}$. Data for $\mathrm{Cu}_{5} \mathrm{FeS}_{4}$ have been included for comparison purposes.

The substitution of copper for iron concomitantly with the introduction of cation vacancies in materials of general formula $\mathrm{Cu}_{4 \cdot 94+\mathrm{z}} \mathrm{Fe}_{1-\mathrm{z}} \mathrm{S}_{4}(0.02 \leq \mathrm{z} \leq 0.10)$, produces further improvements in TE performance. p-type semiconducting behavior is retained at all compositions (Fig. 9) and both resistivity and Seebeck coefficient decrease with increasing copper content, analogous to the behavior observed in $\mathrm{Cu}_{5-\mathrm{x}} \mathrm{FeS}_{4}$ and $\mathrm{Cu}_{5+\mathrm{y}} \mathrm{Fe}_{1-\mathrm{y}} \mathrm{S}_{4}$. In $\mathrm{Cu}_{4 \cdot 94+\mathrm{z}} \mathrm{Fe}_{1-\mathrm{z}} \mathrm{S}_{4}$ there 
is a compositional range over which the balance between improved electrical conductivity and reduced Seebeck coefficient is optimised and the power factor maximised (Fig. 9). In this region, there are significant enhancements in the power factor when compared to the cationdeficient $(\mathrm{z}=\mathrm{o})$ parent phase, $\mathrm{Cu}_{4.94} \mathrm{FeS}_{4}$ : the power factor at $550 \mathrm{~K}$ increasing from $0.29 \mathrm{~mW} \mathrm{~m}^{-1} \mathrm{~K}^{-2}$ at $\mathrm{z}=0$ to 0.42

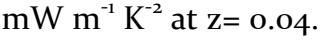

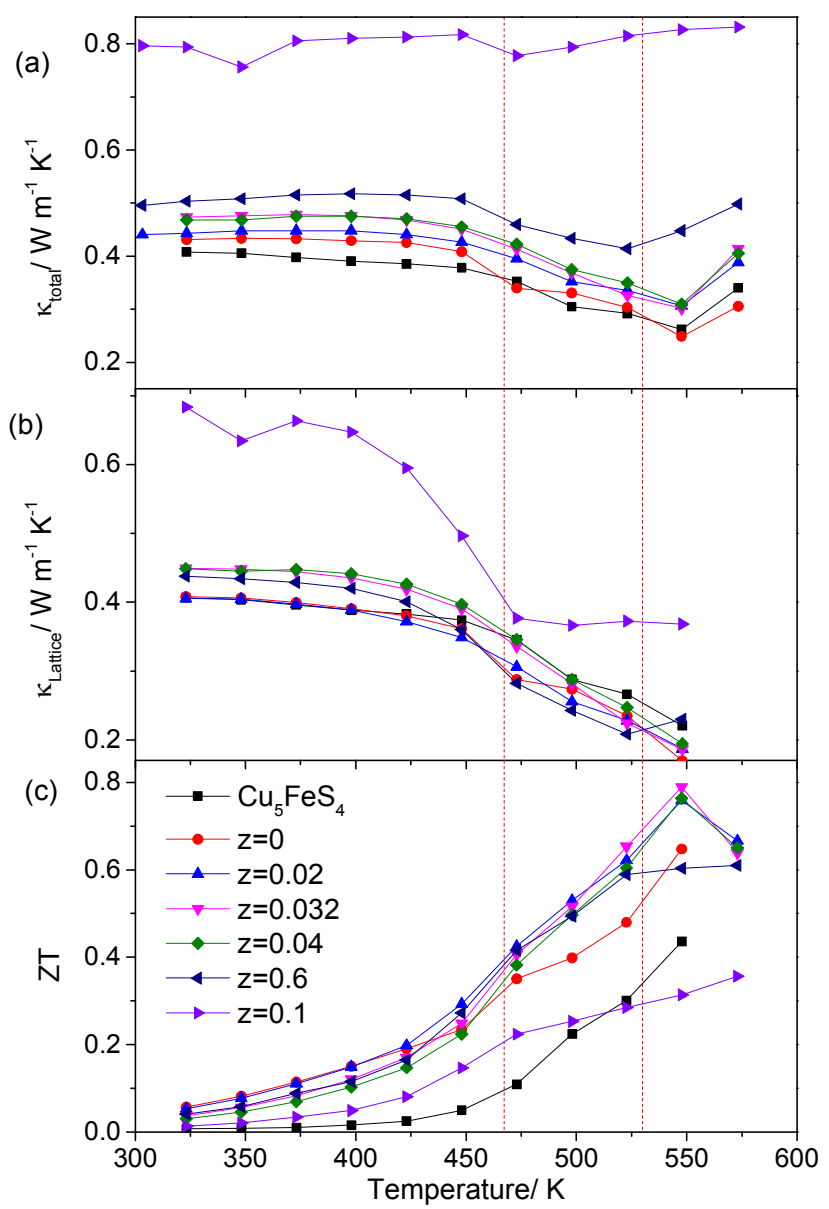

Figure 1o. Temperature dependence of: (a) thermal conductivity; (b) lattice thermal conductivity; (c) thermoelectric figure of merit for $\mathrm{Cu}_{4 \cdot 94+\mathrm{z}} \mathrm{Fe}_{1-\mathrm{z}} \mathrm{S}_{4}(\mathrm{o} \leq \mathrm{z} \leq$ o.1). Data for $\mathrm{Cu}_{5} \mathrm{FeS}_{4}$ have been included for comparison purposes. Red vertical lines indicate the temperatures of the $\mathrm{T}_{1}$ and $\mathrm{T}_{2}$ structural phase transitions in $\mathrm{Cu}_{5} \mathrm{FeS}_{4}$.

With the exception of $\mathrm{Cu}_{5.04} \mathrm{Fe}_{0.9} \mathrm{~S}_{4}$, the thermal conductivity of all $\mathrm{Cu}_{4.94+\mathrm{z}} \mathrm{Fe}_{1-\mathrm{z}} \mathrm{S}_{4}$ phases remains below $0.5 \mathrm{~W} \mathrm{~m}^{-1}$ $\mathrm{K}^{-1}$, increasing only slightly with increasing copper content (Fig. 10). The significantly higher (ca. $0.8 \mathrm{~W} \mathrm{~m}^{-1} \mathrm{~K}^{-1}$ ) thermal conductivity of $\mathrm{Cu}_{5.04} \mathrm{Fe}_{0.9} \mathrm{~S}_{4}$ is attributed to the presence of appreciable amounts of a chalcopyrite impurity, for which the thermal conductivity is in excess of $6 \mathrm{~W}$ $\mathrm{m}^{-1} \mathrm{~K}^{-1}$. Although chalcopyrite has a reasonably high power factor at relatively low temperatures, ${ }^{13}$ we have found that samples with high levels of chalcopyrite impurities have significantly higher thermal conductivities, and hence the best thermoelectric performances are always found for samples within the single-phase regions, as determined by powder X-ray diffraction.

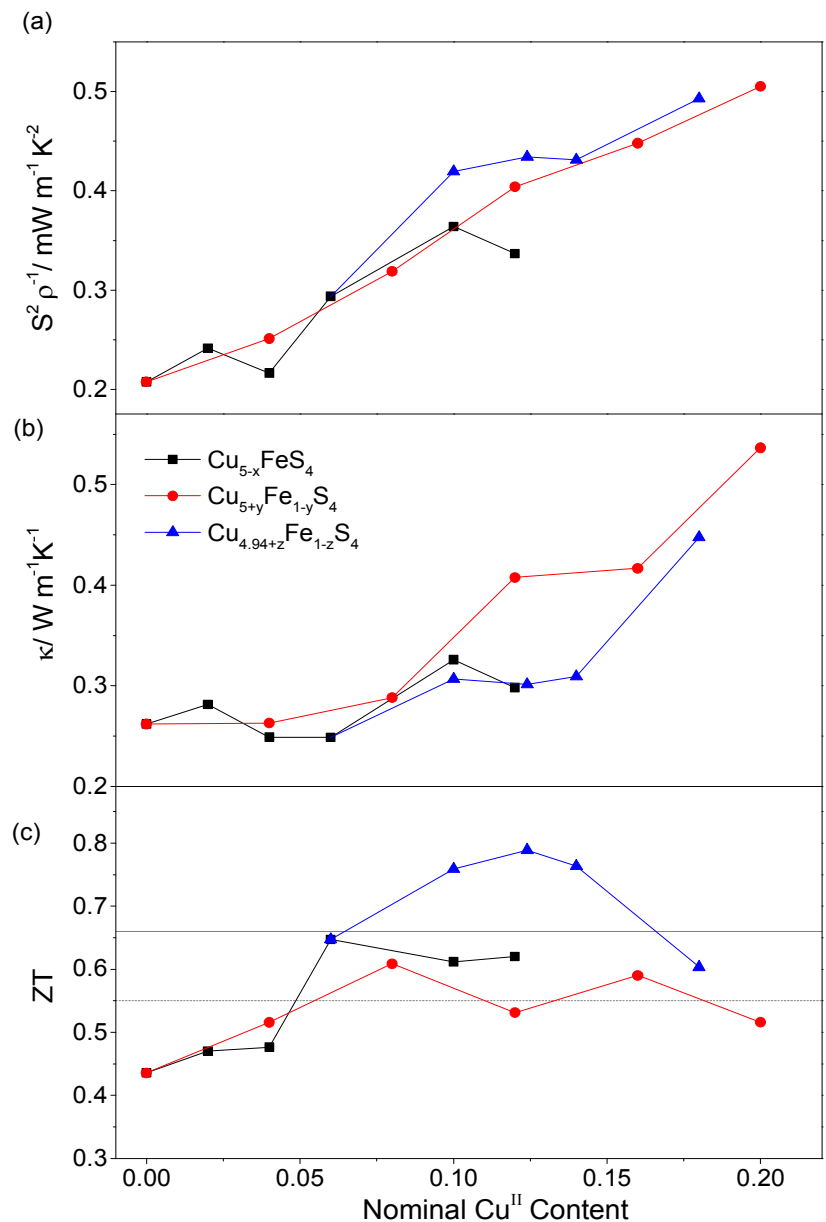

Figure 11. Thermoelectric properties of $\mathrm{Cu}_{5-x+y} \mathrm{Fe}_{1-y} \mathrm{~S}_{4}$ at $550 \mathrm{~K}$ as a function of nominal $\mathrm{Cu}$ (II) content for single phase samples:(a) power factor; (b) thermal conductivity; (c) figure of merit. The solid grey line and the dashed grey line indicate the highest maximum ZT and highest ZT at $550 \mathrm{~K}$ of thermoelectric bornites that have been reported (Table 2).

In the series $\mathrm{Cu}_{4 \cdot 94+\mathrm{z}} \mathrm{Fe}_{1-\mathrm{z}} \mathrm{S}_{4}$, the minimum in $\kappa(\mathrm{T})$ shows no significant compositional dependence at compositions with $\mathrm{z} \leq 0.04$, but shifts to lower temperature for $\mathrm{z}>0.04$. This is analogous to the behaviour of $\mathrm{Cu}_{5+\mathrm{y}} \mathrm{Fe}_{1-\mathrm{y}} \mathrm{S}_{4}$, in which the minimum in $\kappa(\mathrm{T})$ also moved to lower temperatures above a critical $\mathrm{Cu}$ :Fe ratio corresponding to $\mathrm{y}=$ 0.04 (Fig. 8) and is consistent with the phase transition temperatures determined by DSC. The persistence of a negative $d \kappa / d T$ to higher temperatures, where the power factor continues to increase, results in the highest figures of merit determined for bornite-related phases. The figure of merit of $\mathrm{Cu}_{4.94+\mathrm{Z}} \mathrm{Fe}_{1-\mathrm{Z}} \mathrm{S}_{4}$ exceeds $\mathrm{ZT}=0.76$ for samples in the range $0.02 \leq \mathrm{z} \leq 0.04$, with the highest value of $\mathrm{ZT}=$ 0.79 being realised for $\mathrm{Cu}_{4.972} \mathrm{Fe}_{0.968} \mathrm{~S}_{4}$ (Fig. 10). This represents an $88 \%$ increase over the stoichiometric parent phase, $\mathrm{Cu}_{5} \mathrm{FeS}_{4}$. Moreover this performance is achieved at the remarkably low temperature of $550 \mathrm{~K}$, suggesting that these materials are attractive candidates for energy recovery from low-grade waste-heat. The upper temperature for electrical and thermal transport property measurements was limited to $600 \mathrm{~K}$ owing to concerns over sample stability, including the reported appearance of a chalcopyrite-type phase above $550 \mathrm{~K} .{ }^{34}$ However, in previous 
studies ${ }^{23,29,34,35}$ of bornite-related phases, figures of merit at higher temperatures have been reported (Table 2) and the maximum value is generally achieved at ca. 70o K. Therefore the collection of thermal and electrical transport property data was extended to $700 \mathrm{~K}$ for a bornite-type phase close to the optimal composition, $\mathrm{Cu}_{4.97} \mathrm{Fe}_{0.93} \mathrm{~S}_{4}$, identified here (Supplementary Information). Between 550 and $700 \mathrm{~K}$, both the power factor and the thermal conductivity increase with temperature leading to a slight further improvement, of approximately $8 \%$, in the figure of merit achieving a value of $\mathrm{ZT}=0.84$.

3.3 Stability and Application. A key consideration in the application of these materials is long-term stability, given the reported instability in materials such as $\mathrm{Cu}_{2-\mathrm{x}} \mathrm{S}$ which exhibit PLEC behaviour, arising from the migration of copper ions under operating conditions. ${ }^{22}$ It has been proposed that partial substitution of immobile cations into copper sites may be an effective means of suppressing the degradation of copper-containing PLEC materials. ${ }^{37}$ This is supported by recent work on improving the stability of $\mathrm{Cu}_{2} \mathrm{Se}$ by indium substitution. ${ }^{38}$ In order to assess the success of this strategy in the high-performance bornite phase, $\mathrm{Cu}_{4.972} \mathrm{Fe}_{0.968} \mathrm{~S}_{4}$, measurements of electron transport properties on heating were carried out repeatedly over the temperature range $300 \leq \mathrm{T} / \mathrm{K} \leq 575$ (Supplementary Information). No significant change in the TE power factor was observed over the course of eight measurements. This suggests that the presence of the immobile iron cation at tetrahedral sites in the materials reported may indeed suppress diffusion of copper ions by effectively blocking the diffusion pathway.

Previous magnetic and spectroscopic studies of the parent $\mathrm{Cu}_{5} \mathrm{FeS}_{4}$ phase are consistent with $\mathrm{Cu}(\mathrm{I})$ and $\mathrm{Fe}(\mathrm{III})$ formal oxidation states, ${ }^{36,39,40}$ and the introduction of holes requires the oxidation of one of the transition-metal elements. Whilst the presence of Fe(IV) in a sulphide environment would be highly unlikely, a number of mixed valent copper sulphides, containing $\mathrm{Cu}(\mathrm{I})$ and $\mathrm{Cu}(\mathrm{II})$ are known, including $\mathrm{Cu}_{12} \mathrm{Sb}_{4} \mathrm{~S}_{13}{ }^{41}$ and $\mathrm{Cu}_{22} \mathrm{Fe}_{8} \mathrm{Ge}_{4} \mathrm{~S}_{32}{ }^{42}$ Therefore, the three series of bornite-related phases reported here may be directly compared by consideration of the hole content arising from the formation of $\mathrm{Cu}(\mathrm{II})$ as a result of chemical substitution (Fig. 11). All materials may be formulated as $\mathrm{Cu}_{5-x+y} \mathrm{Fe}_{1-y} \mathrm{~S}_{4}$, with the nominal $\mathrm{Cu}(\mathrm{I})$ and $\mathrm{Cu}(\mathrm{II})$ contents given by $(5-2 \mathrm{x}-\mathrm{y})$ and $(\mathrm{x}+2 \mathrm{y})$ respectively. This illustrates that the substitution of iron by copper has

Table 2. Thermoelectric figures of merit for synthetic bornites

\begin{tabular}{l|l|l|l|l} 
Composition & $(\mathrm{ZT})_{\max }$ value & Temperature of $(\mathrm{ZT})_{\text {max }} / \mathrm{K}$ & $\mathrm{ZT} @$ 550K & Reference \\
\hline $\mathrm{Cu}_{4.972} \mathrm{Fe}_{0.968} \mathrm{~S}_{4}$ & 0.84 & 675 & 0.79 & This work \\
$\mathrm{Cu}_{5} \mathrm{Fe}_{1-\mathrm{x}} \mathrm{Mn}_{\mathrm{x}} \mathrm{S}_{4}, \mathrm{x}=0,0.05,0.1$ & 0.55 & 540 & 0.55 & 29 \\
$\mathrm{Cu}_{5} \mathrm{FeS}_{4-\mathrm{x}} \mathrm{Se}_{\mathrm{x}}, \mathrm{x}=0.4$ & 0.66 & 675 & 0.51 & 34 \\
$\mathrm{Cu}_{5+\mathrm{x}} \mathrm{Fe}_{1-\mathrm{x}} \mathrm{S}_{4}, \mathrm{x}=0.04$ & 0.53 & 700 & 0.49 & 23 \\
$\mathrm{Cu}_{5.23} \mathrm{Fe}_{0.9} \mathrm{~S}_{4}$ & 0.56 & 680 & 0.50 & 35
\end{tabular}

a greater impact on the nominal $\mathrm{Cu}$ (II) content than does copper deficiency and therefore a larger hole concentration( $\mathrm{Cu}(\mathrm{II})$ content) may be achieved with smaller deviations from the stoichiometric composition. The power factor for all three series fall on a common trend line and increases almost linearly with $\mathrm{Cu}(\mathrm{II})$ content up to the maximum level of $0.2 \mathrm{Cu}$ (II) achievable through chemical manipulation.

The thermal conductivity shows a more complex dependence on $\mathrm{Cu}(\mathrm{II})$ content. Phases in which full occupancy of cation sites is retained $\left(\mathrm{Cu}_{5+\mathrm{y}} \mathrm{Fe}_{1-\mathrm{y}} \mathrm{S}_{4}\right)$ exhibit a progressive increase in thermal conductivity with increasing $\mathrm{Cu}(\mathrm{II})$ content, principally due to an increased chargecarrier contribution. This contrasts with the behaviour of vacancy-containing phases which exhibit only a weak dependence on hole concentration up to a $\mathrm{Cu}$ (II) content of $c a$. 0.15. The combination of an almost compositionally-invariant thermal conductivity and a rising power factor, leads to maximum figures of merit being achieved at $\mathrm{Cu}(\mathrm{II})$ contents in the region of $0.10-0.15$. Moreover, comparison of the two cation-deficient series of materials, $\mathrm{Cu}_{5-\mathrm{x}} \mathrm{FeS}_{4}$ and $\mathrm{Cu}_{4 \cdot 94+\mathrm{z}} \mathrm{Fe}_{1-\mathrm{z}} \mathrm{S}_{4}$ reveals that in addition to the hole concentration, a critical level of vacancies, in the region of ca. $1 \%$, is required in order to achieve the highest figures of merit as exemplified by $\mathrm{Cu}_{4.972} \mathrm{Fe}_{0.968} \mathrm{~S}_{4}$, which has a $\mathrm{Cu}$ (II) content of 0.124 and a vacancy concentration of $1 \%$. This is a nominal vacancy level, based on compositions determined by EDX are in good agreement with the nominal compositions.

This investigation has led to a significant increase in the maximum ZT of bornite-related phases, as shown in Table 2. A large number of the non-stoichiometric materials reported here exhibit values in the range $0.59<\mathrm{ZT}<0.80$ at $550 \mathrm{oK}$, representing an increase of up to $44 \%$, with respect to previous reports. Although prior to this work, the impact of transition-metal substitution on the TE properties of bornites has been little explored, ${ }^{29}$ it has been shown recently that the partial substitution of sulphur by selenium has a significant effect on the transport properties. $^{34}$ This suggests that anion substitution, combined with the use of cation substitution coupled with the creation of vacancies described here, may prove to be a highly-effective approach to achieving further enhancements in TE performance. the ideal formula for bornite, but as shown in Table 1 , the 


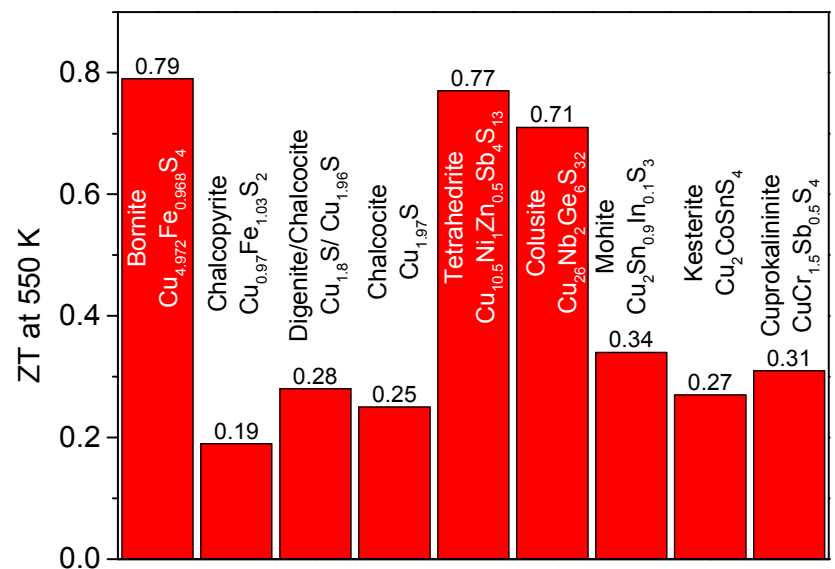

Figure 12. $\mathrm{ZT}$ values at $550 \mathrm{~K}$ for a range of copper sulphide minerals. The highest reported ZT value for each mineral is given. ${ }^{15,17,18,43-47}$

The high level of interest in copper sulphides for TE applications ${ }^{15,17,18,43-47}$ has been driven by a combination of promising performance, coupled with the earthabundance of the constituent elements. ${ }^{48}$ Although materials such as those related to tetrahedrite exhibit a higher absolute maximum figure of merit, the materials reported here are among the highest performing thermoelectrics at temperatures appropriate to energy recovery from low- to mid-range waste heat available in industrial processes (Fig. 12). Indeed the figure of merit of $\mathrm{Cu}_{4.972} \mathrm{Fe}_{0.968} \mathrm{~S}_{4}$ and of substituted tetrahedrites are essentially the same in this temperature range.

\section{Conclusion}

The work reported here demonstrates that deviations from the ideal $\mathrm{Cu}_{5} \mathrm{FeS}_{4}$ stoichiometry produce significant enhancements in the electrical transport properties of bornite, whilst maintaining a low thermal conductivity. This leads to increases of up to $88 \%$ in the TE figure of merit. Moreover, the presence of iron on tetrahedral sites appears to suppress the degradation arising from copper ion-mobility in structurally-related PLEC-type materials. Thermal cycling data and constant current stress tests ${ }^{23}$ suggest that reasonable device lifetimes could be achievable. Whilst impurity formation, principally chalcopyrite, is evident at higher levels of chemical substitution, this does not significantly impact on the TE properties at low chalcopyrite levels. Bornite-related materials remain relatively unexplored as a class of TE material, suggesting that there is considerable scope to achieve further enhancements in TE performance through chemical substitution.

\section{ASSOCIATED CONTENT}

Supporting Information. Powder X-ray diffraction data, DSC data and additional thermal conductivity, electrical property and thermoelectric data. This material is available free of charge via the Internet at http://pubs.acs.org.

\section{AUTHOR INFORMATION}

\section{Corresponding Author}

*E-mail: a.v.powell@reading.ac.uk

\section{Funding Sources}

Financial support from the University Reading and the ISIS neutron facility (STFC) is greatly acknowledged.

\section{ACKNOWLEDGMENT}

The authors would like to thank the Science and Technology Facilities Council and The University of Reading for a Facility Development Studentship for S. Long and the Chemical Analysis Facility at The University of Reading for access to XRay Diffraction, DSC and SEM equipment.

\section{ABBREVIATIONS}

EDX, Energy Dispersive X-Ray; DSC, Differential Scanning Calorimetry; SEM, Scanning Electron Microscope; TE, Thermoelectric, $\mathrm{T}_{1}$, low to intermediate phase transition; $\mathrm{T}_{2}$, intermediate to high phase transition.

\section{REFERENCES}

(1) Rowe, D. M. Thermoelectrics, an Environmentally-Friendly Source of Electrical Power. Renew. Energy 1999, 16, 1251-1256.

(2) Bell, L. E. Cooling, Heating, Generating Power, and Recovering Waste Heat with Thermoelectric Systems. Science 2oo8, 321, 1457-1461.

(3) Zhou, Z.; Yang, J.; Jiang, Q.; Li, W.; Luo, Y. Large Improvement of Device Performance by a Synergistic Effect of Photovoltaics and Thermoelectrics. Nano Energy 2016, 22, 120-128.

(4) Bjørk, R.; Nielsen, K. K. The Performance of a Combined Solar Photovoltaic and Thermoelectric Generator System. Sol. Energy 2015, 120, 187-194.

(5) Kajikawa, T. Thermoelectric Power Generation System Recovering Industrial Waste Heat. In Thermoelectrics Handbook: Macro to Nano; Rowe, D. M., Ed.; CRC Press: Boca Raton, 2006; pp 50-1 - 50-26.

(6) Johnson, I.; Chocate, W. T.; Davidson, A. Waste Heat Recovery: Technology and Oppertunities in U.S. Industry; United States Department of Energy, Office of Energy Efficiency and Renewable Energy. 2008, DOI: 10.2172/1218716.

(7) Venkatasubramanian, R.; Siivola, E.; Colpitts, T.; O’Quinn, B. Thin-Film Thermoelectric Devices with High RoomTemperature Figures of Merit. Nature 2011, 413, 597-602.

(8) Poudel, B.; Hao, Q.; Ma, Y.; Lan, Y.; Minnich, A.; Yu, B.; Yan, X.; Dresselhaus, M. S.; Chen, G.; Ren, Z. HighThermoelectric Performance of Nanostructured Bismuth Antimony Telluride Bulk Alloys. Science, 20o8, 320 (May), 634-638.

(9) Lu, X.; Morelli, D. T. Natural Mineral Tetrahedrite as a Direct Source of Thermoelectric Materials. Phys. Chem. Chem. Phys. 2013, 15, 5762-5766.

(10) Beeken, R. B.; Garbe, J. J.; Petersen, N. R.; Stoneman, M. R. Electrical Properties of the $\mathrm{Ag}_{6} \mathrm{PSe}_{5} \mathrm{X}(\mathrm{X}=\mathrm{Cl}, \mathrm{Br}, \mathrm{I})$ Argyrodites. J. Phys. Chem. Solids 2004, 65, 1011-1014.

(11) Sun, B.-Z.; Ma, Z.; He, C.; Wu, K. Anisotropic Thermoelectric Properties of Layered compounds in $\mathrm{SnX}_{2}(\mathrm{X}=\mathrm{S}, \mathrm{Se})$ : a promising thermoelectric material. Phys. Chem. Chem. Phys. 2015, 17, 29844-29853.

(12) Maignan, A.; Guilmeau, E.; Gascoin, F.; Breard, Y.; Hardy, V. Revisiting some chalcogenides for thermoelectricity. Sci. Technol. Adv. Mater. 2012, 13, 053003.

(13) Ang, R.; Khan, A.U.; Tsujii, N.; Takai, K.; Nakamura, R.; Mori, T. Thermoelectricity Generation and Electron-Magnon Scattering in a Natural Chalcopyrite Mineral from a Deep-Sea Hydrothermal Vent. Angew. Chem. Int. Ed. 2015, 54, 12909 -12913.

(14) Zhang, R-Z.; Chen, K.; Du, B.; Reece, M.J. Screening for $\mathrm{Cu}-\mathrm{S}$ based thermoelectric materials using crystal structure features. J. Mater. Chem. A 2017, 5, 5013-5019. 
(15) Khan, A. U.; Al Orabi, R. A. R.; Pakdel, A.; Vaney, J.B.; Fontaine, B.; Gautier, R.; Halet, J.-F.; Mitani, S.; Mori, T. Sb Doping of Metallic $\mathrm{CuCr}_{2} \mathrm{~S}_{4}$ as a Route to Highly Improved Thermoelectric Properties. Chem. Mater. 2017, 29, 2988-2996.

(16) Heo, J.; Laurita, G.; Muir, S.; Subramanian, M. A.; Keszler, D. A. Enhanced Thermoelectric Performance of Synthetic Tetrahedrites. Chem. Mater. 2014, 26, 2047-2051.

(17) Lu, X.; Morelli, D. T.; Xia, Y.; Ozolins, V. Increasing the Thermoelectric Figure of Merit of Tetrahedrites by Co-Doping with Nickel and Zinc. Chem. Mater. 2015, 27, 408-413.

(18) He, Y.; Day, T.; Zhang, T.; Liu, H.; Shi, X.; Chen, L.; Snyder, G. J. High Thermoelectric Performance in Non-Toxic Earth-Abundant Copper Sulfide. Adv. Mater. 2014, 26, 39743978.

(19) Liu, H.; Shi, X.; Xu, F.; Zhang, L.; Zhang, W.; Chen, L.; Li, Q.; Uher, C.; Day, T.; Snyder, G. J. Copper Ion Liquid-like Thermoelectrics. Nat. Mater. 2012, 11, 422-425.

(20) Weldert, K. S.; Zeier, W. G.; Day, T. W.; Panthöfer, M.; Snyder, G. J.; Tremel, W. Thermoelectric Transport in $\mathrm{Cu}_{7} \mathrm{PSe}_{6}$ with High Copper Ionic Mobility. J. Am. Chem. Soc. 2014, 136, 12035-12040.

(21) Brown, D. R.; Day, T.; Caillat, T.; Snyder, G. J. Chemical Stability of $(\mathrm{Ag}, \mathrm{Cu})_{2} \mathrm{Se}$ : A Historical Overview. J. Electron. Mater. 2014, 42, 2014-2019.

(22) Dennler, G.; Chmielowski, R.; Jacob, S.; Capet, F.; Roussel, P.; Zastrow, S.; Nielsch, K.; Opahle, I.; Madsen, G. K. H. Are Binary Copper Sulfides/ Selenides Really New and Promising Thermoelectric Materials. Adv. Energy Mater. 2014, 4, 1301581.

(23) Qiu, P.; Zhang, T.; Qiu, Y.; Shi, X.; Chen, L. Sulfide Bornite Thermoelectric Material: A Natural Mineral with Ultralow Thermal Conductivity. Energy Environ. Sci. 2014, 7, 4000-4006.

(24) Morimoto, N. Structures of Two Polymorphic Forms of $\mathrm{Cu}_{5} \mathrm{FeS}_{4}$. Acta Crystallogr. 1964, 17, 351.

(25) Kanazawa, Y.; Koto, K.; Morimoto, N. Bornite: Stability and Crystal Structure of the Intermediate Form. Canad. Mineral. 1978, 16, 397-404.

(26) Koto, B. Y. K.; Morimoto, N. Superstructure Investigation of Bornite, $\mathrm{Cu}_{5} \mathrm{FeS}_{4}$, by the Modified Partial Patterson Function. Acta Crystallogr. 1975, 31, 2268-2273.

(27) Ding, Y. Possible Fe/Cu Ordering Schemes in the 2a Superstructure of Bornite $\left(\mathrm{Cu}_{5} \mathrm{FeS}_{4}\right)$. Amer. Miner. 2005, 90, 12651269.

(28) Larson; A.C.; Von Dreele, R.B. General Structure Analysis System. Los Alamos National Laboratory Report LAUR 1994, 86784 .

(29) Guélou, G.; Powell, A. V.; Vaqueiro, P. Ball Milling as an Effective Route for the Preparation of Doped Bornite: Synthesis, Stability and Thermoelectric Properties. J. Mater. Chem. C 2015, 3, 10624-10629.

(30) Cowan, R. D. Pulse Method of Measuring Thermal Diffusivity at High Temperatures. J. Appl. Phys. 1963, 34, 926-927.

(31) Ding, Y.; Veblen D.R.; Prewittt, C.T. High-Resolution Transmission Electron Microscopy Study of the 4a and 6a Superstructure of Bornite $\mathrm{Cu}_{5} \mathrm{FeS}_{4}$. Amer. Miner. 2005, 90, 1256-1264.

(32) Wiltrout, A. M.; Freymeyer, N. J.; Machani, T.; Rossi, D. P.; Plass, K. E. Phase-Selective Synthesis of Bornite Nanoparticles. J. Mater. Chem. 2011, 21, 19286.
(33) Grguric, B. A.; Putnis, A. Controls on Phase Transition Temperatures in Bornite: a differential Scanning Calorimetry Study Canad. Mineral. 1998, 36, 215-226.

(34) Kumar, V. P.; Barbier, T.; Lemoine, P.; Raveau, B.; Nassif, V.; Guilmeau, E. The Crucial Role of Selenium for Sulphur Substitution in the Structural Transitions and Thermoelectric Properties of $\mathrm{Cu}_{5} \mathrm{FeS}_{4}$ Bornite. Dalton. Trans. 2017, 46, 2174-2183.

(35) Zhang, A.; Shen, X.; Zhang, Z.; Lu, X.; Yao, W.; Dai, J.; Xie, D.; Guo, L.; Wang, G.; Zhou, X. Large-Scale Colloidal Synthesis of $\mathrm{Cu}_{5} \mathrm{FeS}_{4}$ Compounds and Their Application in Thermoelectrics. J. Mater. Chem. $C$ 2017, 5, 301.

(36) Townsend, M. G.; Gosselin, J. R.; Tremblay, R. J.; Ripley, L. G.; Carson, D. W.; Muir, W. B. A Magnetic and Mossbauer Study of Magnetic Ordering and Vacancy Clustering in $\mathrm{Cu}_{5} \mathrm{FeS}_{4}$. J. Phys. Chem. Solids 1977, 38, 1153-1159.

(37) Qiu, P.; Shi, X.; Chen, L. Cu-Based Thermoelectric Materials. Energy Storage Mater. 2016, 3, 85-97.

(38) Olvera, A. A.; Moroz, N. A.; Sahoo, P.; Ren, P.; Bailey, T. P.; Page, A. A.; Uher, C.; Poudeu, P. F. P. Partial Indium Solubility Induces Chemical Stability and Colossal Thermoelectric Figure of Merit in $\mathrm{Cu}_{2}$ Se. Energy Environ. Sci. 2017, 10, 1668-1676.

(39) Collins, M.F.; Longworth, G.; Townsend, M. G. Magnetic structure of bornite. Can J. Phys. 1981, 59, 535-539.

(40) van der Laan, G.; Pattrick, R.A.D.; Henderson, C.M.B.; Vaughan, D.J. Oxidation state variations in copper minerals studied with $\mathrm{Cu} 2 \mathrm{p} \mathrm{X}$-ray absorption spectroscopy. J. Phys. Chem. Solids 1992, 53, 1185-1190.

(41) Di Benedetto, F.; Bernardini, G.P.; Cipriani, C.; Emiliani, C.; Gatteschi, D.; Romanelli, M. The distribution of $\mathrm{Cu}(\mathrm{II})$ and the magnetic properties of the synthetic analogue of tetrahedrite: $\mathrm{Cu}_{12} \mathrm{Sb}_{4} \mathrm{~S}_{13}$. Phys. Chem. Minerals 2005, 32, 155-164

(42) Kumar, V.P.; Paradis-Fortin, L.; Lemoine, P.; Caignaert, V.; Raveau, B.; Malaman, B.; Le Caër, G.; Cordier, S.; Guilmeau, E. Designing a Thermoelectric Copper-Rich Sulfide from a Natural Mineral: Synthetic Germanite $\mathrm{Cu}_{22} \mathrm{Fe}_{8} \mathrm{Ge}_{4} \mathrm{~S}_{32}$ Inorg. Chem. 2017, 56, 13376-13381.

(43) Ge, Z.-H.; Zhang, B.-P.; Chen, Y.-X.; Yu, Z.-X.; Liu, Y.; Li, J.-F. Synthesis and Transport Property of $\mathrm{Cu}_{1.8} \mathrm{~S}$ as a Promising Thermoelectric Compound. Chem. Commun. 2o11, 47, 1269712699.

(44) Bouyrie, Y.; Ohta, M.; Suekuni, K.; Kikuchi, Y.; Jood, P.; Yamamotoa, A.; Takabatake, T. Enhancement in the Thermoelectric Performance of colusites $\mathrm{Cu}_{26} \mathrm{~A}_{2} \mathrm{E}_{6} \mathrm{~S}_{32}(\mathrm{~A}=\mathrm{Nb}, \mathrm{Ta}, \mathrm{E}=\mathrm{Sn}$, $\mathrm{Ge})$ using E-site non-stoichiometry. J. Mater. Chem. C 2017, 5, 4174-4184.

(45) Tan, Q.; Sun, W.; Li, Z.; Li, J. Enhanced Thermoelectric Properties of Earth-Abundant $\mathrm{Cu}_{2} \mathrm{SnS}_{3}$ via In Doping Effect. $J$. Alloys Compd. 2016, 672, 558-563.

(46) Xiao, C.; Li, K.; Zhang, J.; Tong, W.; Liu, Y.; Li, Z.; Huang, P.; Pan, B.; Su, H.; Xie, Y. Magnetic Ions in Wide Band Gap Semiconductor Nanocrystals for Optimized Thermoelectric Properties. Mater. Horizons 2014, 1, 81-86.

(47) Li, Y.; Zhang, T.; Qin, Y.; Day, T.; Snyder, G. J.; Shi, X.; Chen, L. Thermoelectric Transport Properties of Diamond-like $\mathrm{Cu}_{1-\mathrm{x}} \mathrm{Fe}_{1+\mathrm{X}} \mathrm{S}_{2}$ Tetrahedral Compounds. J. Appl. Phys. 2014, 116, 203705 .

(48) Suekuni, K.; Takabatake, T. Research Update : Cu-S Based Synthetic Minerals as Efficient Thermoelectric Materials at Medium Temperatures. APL Mater. 2016, 4, 104503. 


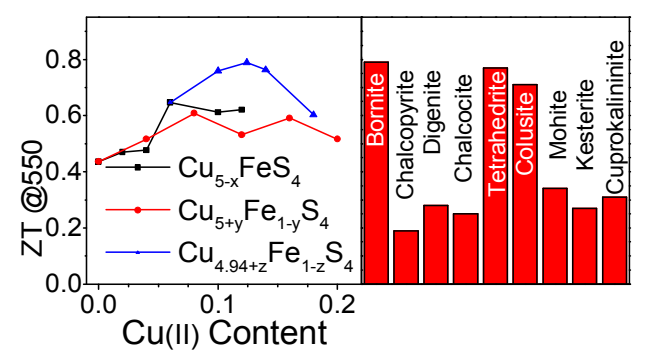

